\author{
Urszula Batorska \\ II Liceum Ogólnokształcące \\ im. Króla Jana III Sobieskiego, Kraków
}

\title{
Rodzaje i struktura bezrobocia w Polsce
}

W programie treści kształcenia w nowym przedmiocie wkraczającym do systemu edukacyjnego podstawy przedsiębiorczości" bardzo ważnym zagadnieniem jest problematyka rynku pracy i bezrobocia.

Należy przy tym podkreślić, że bezrobocie jest stosunkowo nowym zjawiskiem w Polsce, które pojawiło się po 1989 roku wraz z wdrażaniem systemu gospodarki rynkowej. Poprzedni system centralnego sterowania, poprzez szereg instrumentów administracyjnych, nie dopuszczał do rozwijania zjawiska bezrobocia. Wynikało to z założeń ideologicznych, z których istniejący system zapewniał każdemu obywatelowi miejsce pracy. Uruchomiło to jednak negatywne zjawisko tzw. przerostu zatrudnienia, które w znacznym stopniu obniżało efektywność pracy oraz wzmagało ekstensywność czynników rozwoju. „Izolacja polityczna i związana z nią izolacja gospodarcza państw byłej RWPG, centralny podział zadań produkcyjnych, znikome zasady gospodarki rynkowej i mała konkurencyjność wyrobów były dodatkowymi czynnikami powodującymi nieefektywne gospodarowanie, w którym znaczące miejsce miały względy pozaekonomiczne, wynikające z preferencji politycznych i militarnych." (Zioło 1993).

Jeszcze w 1988 roku na 10 tysięcy poszukujących pracy było 254 tysięcy ofert zatrudnienia, co świadczyło o nadwyżce podaży pracy nad jej popytem. Tymczasem w następnych latach wraz z wdrażaniem nowego systemu gospodarowania, diametralnie zmieniła się sytuacja na rynku pracy, czego efektem było pojawiające się nieznane dotychczas bezrobocie. W kolejnych latach stopniowo zwiększała się liczba bezrobotnych z 1126 tys. w 1990 roku do 2628 tys. w 1995 roku i 3300 tys. osób w 2002 roku.

W wyniku rozpadu bloku byłych państw, skupionych w strukturach RWPG załamały się nasze dotychczasowe powiązania gospodarcze, w tym także rynki zbytu. Recesja gospodarcza tych państw w poważnym stopniu ograniczyła dalszy eksport wyrobów i pojawienie się zjawiska nadprodukcji. Wdrażanie gospodarki rynkowej oraz otwarcie jej na rynki zachodnie uruchomiło bardzo ostrą konkurencję między wyrobami krajowymi a wyrobami państw ekonomicznie rozwiniętych. W konsekwencji słabszej konkurencyjności naszych wyrobów polskie produkty nie znajdowały miejsca na rynkach zachodnich. Wprowadzając reguły gospodarki rynkowej niezbędna okazała się zmiana struktury własnościowej, która miała wpłynąć na restrukturyzację i podniesienie konkurencji produktów przemysłowych. Procesy restrukturyzacji, w tym także zmiana struktur własnościowych, wpływały na racjonalizację zarówno asortymentów, jak i rozmiarów produkcji. Wymuszały więc w pierwszym rzędzie podniesienie konkurencyjności, poprzez mi. in. obniżenie kosztów. Pierwszym krokiem w tym zakresie była racjonalizacja zatrudnienia, która pociągnęła za sobą konieczność masowych zwolnień, nie tylko istniejących wcześniej przerostów zatrudnienia, ale także pracowników związanych z małą konkurencyjnością wytwarzanych produktów.

$\mathrm{Z}$ przedstawionych przesłanek wynika przedmiot i cel artykułu. Obecnie bowiem niezwykle ważną kwestią staje się zatem zrozumienie mechanizmów rządzących na rynku pracy 
oraz związanego z nim bezrobocia. Problematyka ta dotyczy szczególnie młodych osób, w tym także w niedalekiej przyszłości uczniów szkół, wśród których obecnie stopa bezrobocia przekracza $30 \%$. (Nasiłowski 2002, s. 107). W artykule zmierzać będę do przedstawienia problematyki bezrobocia, podejmowanej na lekcjach z przedsiębiorczości. Materiały zawarte w niniejszym opracowaniu powinny się przyczynić do przybliżenia tej problematyki nauczycielom i uczniom w procesie edukacyjnym tego przedmiotu.

Szczególną uwagę zwrócę na :pojęcie i rodzaje bezrobocia, przyczyny bezrobocia $\mathrm{w}$ Polsce po 1989 roku, struktury demograficzne bezrobotnych, zróżnicowanie przestrzenne rozmiarów bezrobocia, dynamikę zmian stopy bezrobocia w ciągu roku oraz prognozy bezrobocia na najbliższe 3 lata.

W literaturze przedmiotu wiele miejsca poświęca się problematyce bezrobocia ( $\mathrm{Pa}-$ dowicz 2000, Zioło 1992-93, Dach 1994, 1993-98, Grzywacz 2000). W pracach tych główną uwagę zwrócono na analizę bezrobocia w Polsce pod kątem wybranych cech społeczno demograficznych, jego skutki oraz metody zapobiegania temu niekorzystnemu zjawisku. Zagadnieniami bezrobocia zajmują się ponadto m.in.: M. Nasiłowski (2002), A. Fajferek (1991), B. Winiarski (1999) czy T. Oleksyn (1991, 1992). Szczególnie wiele miejsca problematyce bezrobocia poświęcają liczne czasopisma naukowe (m.in. „Polityka społeczna”, „Praca i zabezpieczenie społeczne”), prasa codzienna i Internet.

W Polsce mamy dwa źródła wiedzy o bezrobociu :bieżącą rejestrację w rejonowych biurach pracy oraz wyniki badań aktywności ekonomicznej ludności (BAEL) przeprowadzanych na grupie reprezentacyjnej przez GUS. Od IV kwartału 1999 roku została zmodyfikowana metoda prowadzenia BAEL, tzn. w miejsce obserwacji wybranego tygodnia, kwartału prowadzi się obserwację ciągłą, czyli w każdym tygodniu całego kwartału.

W literaturze przedmiotu można spotkać różne definicje bezrobocia. Według Urzędu Pracy bezrobotny to osoba niezatrudniona i nie wykonująca innej pracy zarobkowej, zdolna i gotowa do podjęcia zatrudnienia w pełnym wymiarze czasu pracy, nie ucząca się w szkole w systemie dziennym, zarejestrowana we właściwym dla miejsca zameldowania powiatowym urzędzie pracy, jeżeli:

- ukończyła 18 lat (z wyjątkiem młodocianych absolwentów),

- kobieta nie ukończyła 60 lat, a mężczyzna 65 lat,

- nie nabyła prawa do emerytury lub renty z tytułu niezdolności do pracy, nie pobiera zasiłku przedemerytalnego, świadczenia rehabilitacyjnego, zasiłku chorobowego, macierzyńskiego lub wychowawczego,

- nie jest właścicielem lub posiadaczem nieruchomości rolnej o powierzchni użytków rolnych powyżej 2 ha przeliczeniowych,

- nie podlega ubezpieczeniu emerytalno- rentowemu z tytułu stałej pracy jako domownik w gospodarstwie rolnym o powierzchni użytków rolnych przekraczających 2 ha,

- nie podjęła pozarolniczej działalności gospodarczej lub nie podlega - na podstawie odrębnych przepisów - obowiązkowi ubezpieczenia społecznego lub zaopatrzenia emerytalnego,

- jest osobą niepełnosprawną, której stan zdrowia pozwala na podjęcie zatrudnienia co najmniej w połowie wymiaru czasu pracy obowiązującego w danym zawodzie lub służbie,

- nie jest tymczasowo aresztowana lub nie odbywa kary pozbawienia wolności.

Od 1997 roku za bezrobotnego nie uważa się osoby odbywającej szkolenie oraz staż u pracodawcy. Jak przyjmuje W. Grzywacz (2002) mankamentem takiej definicji jest to, że do grupy bezrobotnych zalicza się wyłącznie osoby zarejestrowane w urzędzie pracy. Dużo osób bezrobotnych z różnych względów nie rejestruje się w urzędach pracy, stąd informacje, jakie $\mathrm{z}$ nich docierają są zawsze zaniżone w stosunku do rzeczywistej liczby osób bezrobotnych. 
Bezrobocie jest przedstawiane również jako „sytuacja, w której część osób w wieku produkcyjnym jest skłonnych do podjęcia pracy na typowych warunkach, lecz pomimo poszukiwania nie znajduje zatrudnienia” (wg „Leksykonu przedsiębiorczości”). W ”Słowniku ekonomicznym i finansowym” bezrobocie definiowane jest jako „niepożądany i przedłużający się stan pozostawania bez pracy, spowodowany niemożliwością znalezienia zatrudnienia". Bezrobocie może być także pojmowane jako ,zjawisko braku pracy zarobkowej dla osób zdolnych do pracy i poszukujących jej” („Encyklopedia powszechna PWN”)

Do kategorii bezrobotnych wg GUS zaliczane są osoby w wieku 15 lat i więcej, które spełniają jednocześnie 3 warunki:

- w okresie badanego tygodnia nie były osobami pracującymi, tzn. nie wykonywały pracy przynoszącej zarobek przez co najmniej 1 godzinę,

- aktywnie poszukiwały pracy, tzn. podjęły konkretne działania w ciągu 4 tygodni, wliczając jako ostatni tydzień badany, aby znaleźć pracę,

- były zdolne i gotowe podjąć pracę w tygodniu badanym i następnym.

Osoba, która przepracowała w tygodniu co najmniej 1 godzinę jest już zaliczana do pracujących, a która nie przepracowała 1 godziny - do bezrobotnych. Mimo, że jest to kryterium niezwykle rygorystyczne, odpowiada ono międzynarodowemu standardowi, określonemu przez Międzynarodową Organizację Pracy i stosowane jest w większości krajów rozwiniętych gospodarczo (Grzywacz 2002). Wg Z. Dach (1998) wspólnym elementem łączącym definicję bezrobocia w ustawodawstwach krajów zachodnich jest „fakt pozostawania bez pracy, wbrew własnej woli bezrobotnego"

W literaturze przedmiotu autorzy proponują wiele podziałów bezrobocia, w świetle przyjmowanych często odmiennych kryteriów: cykliczne, frykcyjne, strukturalne, koniunkturalne, dobrowolne, przymusowe, jawne, ukryte, demograficzne, importowane, sezonowe, klasyczne czy keynesistowskie.

Ze względu na czas trwania bezrobocia możemy je podzielić na krótko- i długookresowe. Do bezrobocia krótkookresowego zaliczyć można bezrobocie cykliczne i frykcyjne, w przeciwieństwie do długookresowego bezrobocia strukturalnego (Dach 1998)

Przez bezrobocie frykcyjne (przejściowe) rozumie się nieredukowalne minimum bezrobocia w dynamicznej gospodarce, powstałe w związku z powolnością przystosowań struktury podaży i popytu na siłę roboczą na niedoskonale funkcjonującym rynku pracy. Te niedopasowania (frykcje) między wolnymi miejscami pracy a wolną siłą roboczą wynikają z ciągłych procesów tworzenia, likwidacji lub zmiany miejsc pracy oraz z napływu i odpływu siły roboczej. W rezultacie zawsze musi wystąpić pewna ilość wolnych miejsc pracy i osób bezrobotnych, gdyż musi upłynąć pewien czas zanim bezrobotni znajdą czekające na nich miejsca pracy (Dach 1998)

Bezrobocie strukturalne powstaje w rezultacie niedopasowań struktury podaży i popytu na siłę roboczą, przede wszystkim w aspekcie kwalifikacyjnym, zawodowym i regionalnym. Jest to wynik zmian w gałęziowej i terytorialnej strukturze produkcji oraz technologii wytwarzania. Ma charakter trwały, gdyż jego likwidacja wymaga zazwyczaj zmiany zawodu, kwalifikacji lub miejsca zamieszkania. Na podstawie badań stwierdza się, że pracownicy ze schyłkowych branż są niechętni do przekwalifikowania się tak przydatnego do pracy w nowych, rozwojowych branżach. Do pozostałych przyczyn pogłębiających bezrobocia strukturalne należą: nienadążanie systemu oświatowego za potrzebami rynku, brak zasobów kapitałowych na zatrudnianie wysoko płatnej, wykwalifikowanej siły roboczej, niemobilność terytorialna itp.

Bezrobocie koniunkturalne (cykliczne) wynika z niedostatecznego popytu konsumpcyjnego i inwestycyjnego w gospodarce, co powoduje niski stopień wykorzystania wszelkich zasobów i zdolności produkcyjnych, a więc również i siły roboczej. Słowo „koniunkturalne” oznacza, że po okresach ożywienia gospodarczego następuje okres recesji(zmiany koniunktury gospodarczej). Dużą rolę w zwalczaniu tego rodzaju bezrobocia przypisuje się rządowi, 
który może m.in. obniżyć stawki podatkowe, stymulując wzrost inwestycji lub zwiększyć wydatki z budżetu państwa na budowę np. dróg i inne prace zwiększające zatrudnienie.

Według zachowania pracowników wyróżniamy: bezrobocie dobrowolne (naturalne), obejmujące osoby, które z różnych subiektywnych względów nie podejmują pracy zarobkowej, mimo istnienia wolnych miejsc pracy oraz bezrobocie przymusowe dotyczące osób, które mimo chęci do pracy nie zostają zatrudnione (Stańda, Wierzbowska 2002)

Według oficjalnego zarejestrowania $w$ urzędach pracy bezrobocie dzielimy na: jawne (są to osoby zarejestrowane $\mathrm{w}$ urzędach pracy i uprawnione do zasiłku) oraz ukryte, które dominowało w Polsce w gospodarce socjalistycznej i polegało na zatrudnieniu kilku osób na jedno stanowisko, czego efektem były znacznie niższe pensje i bardzo niska wydajność pracy. Bezrobocie ukryte obejmuje bezrobotnych nie zarejestrowanych w urzędach pracy, pracujących w niepełnym wymiarze czasu pracy, okazjonalnie (dorywczo) lub pracujących na stanowiskach poniżej swoich kwalifikacji. W tej grupie są również osoby nie zwolnione $\mathrm{z}$ pracy, pomimo ich nieprzydatności.

Bezrobocie demograficzne stanowi specyfikę polską i związane jest z wchodzeniem w latach dziewięćdziesiątych w wiek produkcyjny wyżu demograficznego z lat siedemdziesiątych. Bezrobocie ,importowane” polega na sprowadzaniu towarów zagranicznych, co zmusza krajowych producentów do ograniczania produkcji lub wręcz zamykania zakładów Bezrobocie sezonowe jest odmianą bezrobocia koniunkturalnego i wynika z sezonowości produkcji niektórych działów gospodarki, zwłaszcza tych, które wymagają dostosowania do warunków klimatycznych. W Polsce występuje w rolnictwie (np. w przemyśle cukrowniczym), leśnictwie, rybołówstwie i żegludze śródlądowej.

Według przyczyn bezrobocia ekonomiści podzieleni są na dwie grupy. Zwolennicy bezrobocia klasycznego uznają, że w warunkach gospodarki wolnorynkowej występuje tendencja do ustalania się na rynku pracy równowagi charakteryzującej się pełnym zatrudnieniem. Ograniczeniem w funkcjonowaniu mechanizmów rynkowych jest pojawiające się bezrobocie Jest ono związane $\mathrm{z}$ usztywnianiem płac przez związki zawodowe. W ujęciu keynesowskim, przyczyna bezrobocia wynika z niewystarczającego popytu na towary, co powoduje, że producenci zmuszeni są obniżyć koszty produkcji. (Milewski 1994).

Szczegółowymi mechanizmami, które doprowadziły do bezrobocia są:

- restrukturyzacja gospodarki w Polsce prowadzona w trzech obszarach i obejmująca restrukturyzację własnościową (która polega na prywatyzacji państwowych przedsiębiorstw i wzroście sektora prywatnego w systemie własności państwa), restrukturyzację technologiczną (która związana jest z koniecznością wymiany przestarzałej i zużytej technologii produkcji) oraz produktową, czyli zastępowanie produkcji wyrobów materiałochłonnych i energochłonnych nowoczesnymi, konkurencyjnymi wyrobami (Nasiłowski 2002);

- $\quad$ tzw „szok makroekonomiczny” w krajach transformujących się, wynikający :ze spadku produkcji przemysłowej, głównie w przemyśle ciężkim, po 1990 roku (np. w latach 1990-1995 nastąpił w Polsce spadek wydobycia węgla kamiennego o 8 \% tj z $148 \mathrm{mln} \mathrm{t}$ do $137 \mathrm{mln}$ ton, produkcja stali surowej zmniejszyła się o prawie $15 \% \mathrm{tj}$ z 13,6 mln ton do 11,9 mln ton a ilość produkowanych obrabiarek do metali spadła dwukrotnie z 27,6 tys sztuk do 13,8 tys. sztuk), deficytu w obrotach handlowych z zagranicą (szczególnie z Europą Wschodnią), niekonkurencyjności polskiej produkcji i usług, dewaluacji waluty w stosunku do walut światowych, ograniczenia dofinansowania ze środków budżetowych deficytowych przedsiębiorstw państwowych (np. górnictwa węglowego), upadku nieefektywnych przedsiębiorstw państwowych (np. PGR-ów w Polsce), maksymalnego ograniczenia produkcji zbrojeniowej, uwolnienia cen, konieczności uwzględniania w gospodarce „zasad zrównoważonego rozwoju”, zadłużenia wobec zagranicy, fiskalizmem (Grzywacz W. 2002);

- redukcja zatrudnienia socjalnego (tzw bezrobocia ukrytego), wynikająca z polityki racjonalnego zatrudnienia; 
- niski poziom gospodarczy wielu regionów kraju (np. pogranicza wschodniego) przy jednoczesnym ukrytym bezrobociu agrarnym;

- duży przyrost osób w wieku produkcyjnym jako następstwo wyżu demograficznego, przejawiający się postępującym procesem starzenia się ludności w Polsce. Wg danych z rocznika statystycznego liczba ludności w wieku poprodukcyjnym w Polsce zwiększyła się z 4903 tys. w 1990 roku do 5684 tys. w 2000 roku tj o 15\%.

- $\quad$ sztywny kodeks pracy wynikający m.in. z masowych zwolnień grupowych, wzrastającego bezrobocia, ochrony związków zawodowych itp. Pracodawca musi dziś płacić wysokie odszkodowania z tytułu zwolnień indywidualnych i grupowych. Liczyć się musi również z długim okresem wypowiedzenia pracy, opłatą składek ZUS czy zasiłkiem chorobowym;

- mała mobilność i aktywność zawodowa osób, poszukujących pracy (pasywna postawa bezrobotnych), co wynika z niechęci podnoszenia swoich kwalifikacji, przekwalifikowania się do nowych zawodów oraz zmiany miejsca zamieszkania;

- nadopiekuńczość państwa poprzez wysoki względnie poziom zasiłków dla bezrobotnych, bezpłatną opiekę lekarską;

- zły stan pośrednictwa biur pracy i zakres luki informacyjnej utrudniający redukcję bezrobocia;

- niedostosowanie poziomów i struktury kształcenia do potrzeb rynku pracy;

- liberalna polityka celna, doprowadzająca do tzw. ,importu bezrobocia”;

- wygasanie klauzul ochronnych w dziedzinie zatrudnienia (na ogół 3-letnich), zawartych $\mathrm{z}$ inwestorami zagranicznymi.

W latach 1990-98 zaznaczyły się zasadniczo 3 okresy zmian w zakresie rozmiarów i struktury bezrobocia w Polsce (tab. 1).

Tab. 1. Zmiany bezrobocia w Polsce w latach 1990-2001.

\begin{tabular}{|c|c|c|}
\hline Rok & $\begin{array}{c}\text { Liczba zarejestrowanych osób } \\
\text { poszukujących pracy }\end{array}$ & $\begin{array}{c}\text { Stopa bezrobocia } \\
\text { w \% }\end{array}$ \\
\hline 1990 & 1126140 & 6,5 \\
1991 & 2155573 & 12,2 \\
1992 & 2509342 & 14,3 \\
1993 & 2889601 & 16,4 \\
1994 & 2838038 & 16,0 \\
1995 & 2628808 & 14,9 \\
1996 & 2359489 & 13,2 \\
1997 & 1826413 & 10,3 \\
1998 & 1831351 & 10,4 \\
1999 & 2349805 & 13,1 \\
2000 & 2702576 & 15,1 \\
2001 & 3115000 & 17,4 \\
\hline
\end{tabular}

Źródło: Rocznik statystyczny, GUS, Warszawa 2001

Pierwszy okres obejmuje lata 1990-93, w których następuje wzrost liczby bezrobotnych. O ile tempo wzrostu liczby bezrobotnych w latach 1990-91 było bardzo duże i wyniosło prawie 100\% (z 1126140 bezrobotnych w roku 1990 do $2155573 \mathrm{w}$ roku 1991) o tyle w kolejnych latach badanego okresu tempo to uległo znacznemu zahamowaniu. Jest to wynikiem wprowadzenia nowych przepisów zmieniających definicję osoby bezrobotnej oraz ograniczających uprawnienia do pobierania zasiłków (Ustawa z dnia 16. 10. 1991 o zatrudnieniu i bezrobociu; Dz. U. nr 106, poz 457). Zawieszono organizowanie i finansowanie aktywnych działań zapobiegających skutkom bezrobocia (m. in zaprzestano udzielania pożyczek bezrobotnym na podjęcie działalności gospodarczej oraz zakładom pracy na tworzenie 
dodatkowych miejsc pracy), koncentrując uwagę biur pracy na zapewnienie środków na wypłaty zasiłków (Dach 1998)

Początkowe narastanie skali bezrobocia w Polsce było uwarunkowane uwalnianiem się mechanizmów rynkowych, ogólną recesją gospodarczą, przejawiającą się spadkiem produkcji przemysłowej w 1990 roku o blisko jedną czwartą, restrukturyzacją gospodarki, redukcją bezrobocia ukrytego. Zaczęły się zwolnienia zbędnych pracowników (np. zlikwidowano PGR-y, wprowadzono cięcia kadrowe w polskim górnictwie, zakładach włókienniczych w Łodzi).

Drugi okres przejściowego spadku bezrobocia w Polsce obejmuje lata 1993-98 i był podyktowany wzrostem zatrudnienia w małych i średnich przedsiębiorstwach, napływem kapitału zagranicznego, szczególnie w latach 1995-98. Na zmniejszenie stopy bezrobocia wpłynęło również zahamowanie zwolnień pracowników przedsiębiorstw państwowych, które zredukowały zbędną liczbę pracujących w poprzednim okresie.

Trzeci okres, od 1998 roku, charakteryzuje się ponownym wzrostem bezrobocia $\mathrm{z}$ 1831 tys. w roku 1998 (ze stopą bezrobocia wynoszącą 10,4\%) do 3115 tys. w roku 2001 (odpowiednio 17,4 \%). Przyczynami takiego stanu rzeczy są: zwolnienia tempa wzrostu gospodarczego, osłabienie tempa wzrostu w krajach UE wraz z załamaniem się koniunktury w wielu krajach pozaeuropejskich oraz nasilenie się zwolnień grupowych w przedsiębiorstwach o dużym udziale kapitału zagranicznego, w których kończyły się okresy chroniące załogi przed redukcją (Padowicz 2002). Postępujący od roku 2000 przyspieszony proces restrukturyzacji w podstawowych działach gospodarki spowodował dalszy spadek zatrudnienia (tab. 2). W porównaniu do roku 1999 nastąpił spadek zatrudnienia o 610 tys. osób; w tym w sektorze rolniczym 13 tys., przemysłowym 329 tys. i usługowym 251 tys.

Tab. 2. Liczba zatrudnionych, zwolnionych i przewidzianych do zwolnienia do roku 2001 w wybranych przedsiębiorstwach w Polsce.

\begin{tabular}{|l|c|c|}
\hline $\begin{array}{c}\text { Wybrane przedsiębior- } \\
\text { stwa }\end{array}$ & $\begin{array}{c}\text { Liczba zwolnionych } \\
\text { i do zwolnienia do roku 2001 }\end{array}$ & $\begin{array}{c}\text { Liczba } \\
\text { zatrudnionych }\end{array}$ \\
\hline TP S. A. & 10000 & 69000 \\
Exbud Skanska & 3000 & 14000 \\
Mostostal Export & 2500 & 7500 \\
PKP & 2000 & 155000 \\
Daewoo FSO & 1300 & 4400 \\
BHP & 1200 & 6500 \\
Stocznia Szczecińska & 1100 & 5500 \\
PBK & 1000 & 8000 \\
PLL LOT & 808 & 4700 \\
Netia & 150 & 1600 \\
Zelmer & 400 & 2700 \\
Polar & 700 & 3700 \\
Elektrownia Połaniec & 700 & 2300 \\
\hline
\end{tabular}

Źródło: Newsweek 11/2001, Stasik D. ”Żonglerka pracą", s. 54

W dalszej części pracy dokonam charakterystyki struktury bezrobocia w Polsce wg wybranych cech społeczno-demograficznych.

Najwyższy udział bezrobotnych występuje w pierwszym przedziale wiekowym od 18-24 lat osiągając, w grudniu 2000 roku, wartość 30,47 \%. (tab. 3) Tak wysoki udział najmłodszej grupy bezrobotnych wynika z następujących przyczyn:

- niskiego stażu pracy lub braku stażu,

- niskiego poziomu wykształcenia w stosunku do starszych grup wiekowych,

- $\quad$ wkraczaniem w wiek produkcyjny roczników z wtórnego wyżu demograficznego, 
Wysoki udział bezrobotnych w wieku do 34 lat, wynoszący ponad 56\% ogółu poszukujących pracy, jest zjawiskiem bardzo niekorzystnym. Osoby te są bowiem na etapie zakładania rodzin, poszukiwania mieszkań czyli tzw. „dorabiania się”. Badania psychologów wykazały (m.in. Frąckiewicz 1991, Juraś-Krawczyk 2000, Koptas 1992), że brak pracy sprzyja frustracji, hamuje rozwój osobowości, budzi lęk o przyszłość oraz rodzi zachowania patologiczne. Najmniejszy udział bezrobotnych występuje natomiast w przedziale wiekowym od 55 lat i więcej (1,76\% ogólnego udziału). Grupa wiekowa od 55-64 lat stanowi w Polsce tylko 8,6\% ogółu ludności, stąd zauważa się również mały udział bezrobotnych $\mathrm{z}$ tego przedziału wiekowego. Wiele osób może korzystać już w tym wieku z wcześniejszych emerytur, z zasiłku przedemerytalnego czy renty, co zmniejsza liczbę bezrobotnych. Sądzę, że do niskiego udziału bezrobotnych $\mathrm{z}$ tej grupy przyczynia się zapewne fakt ochrony pracowników, szczególnie z dużym stażem pracy, w przedsiębiorstwach państwowych ze strony związków zawodowych. Poważnym problemem staje się bezrobocie wieku średniego, stanowiące w grupie od 35 do 54 lat ponad 41\% udziału bezrobotnych (tab. 3). Osoby, które utraciły pracę $\mathrm{w}$ tych grupach wiekowych, mają poważne problemy z jej ponownym znalezieniem. Wystarczy przeanalizować najczęstsze oferty pracy, które pracodawcy w większości kierują do osób młodych, maksymalnie do 40 lat.

Tab. 3. Bezrobocie wg wieku w Polsce.

\begin{tabular}{|c|c|c|c|}
\hline Przedziały wiekowe & $\begin{array}{c}\text { Udział \% w ogólnej } \\
\text { liczbie ludności }\end{array}$ & $\begin{array}{c}\text { Liczba } \\
\text { bezrobotnych }\end{array}$ & $\begin{array}{c}\text { Udział \% w ogólnym } \\
\text { bezrobociu }\end{array}$ \\
\hline $18-24$ & 11,6 & 823489 & 30,47 \\
$25-34$ & 13,6 & 713210 & 26,39 \\
$35-44$ & 15,0 & 656452 & 23,18 \\
$45-54$ & 14,5 & 461882 & 18,20 \\
$55-59$ & 4,2 & 38299 & 1,42 \\
$60-64$ & 4,4 & 9244 & 0,34 \\
\hline
\end{tabular}

Źródło: 1) Krajowy Urząd Pracy, 2) Rocznik statystyczny, GUS, Warszawa 2001

Według poziomu wykształcenia największą grupę stanowią bezrobotni mający wykształcenie zasadnicze zawodowe (około 37\%) oraz bezrobotni z wykształceniem pełnym lub niepełnym podstawowym $(33,4 \%)$. Najmniejszą grupę stanowią natomiast bezrobotni z wykształceniem wyższym $(2,6 \%)$ oraz średnim ogólnokształcącym $(6,2 \%)$ - tab. 4.

Tab. 4. Bezrobocie wg poziomu wykształcenia w Polsce.

\begin{tabular}{|l|r|r|r|}
\hline \multirow{2}{*}{ Wyszczególnienie } & \multicolumn{1}{|c|}{1995} & \multicolumn{2}{|c|}{2000} \\
\cline { 2 - 4 } & \multicolumn{1}{|c|}{ \% $\%$} & w \% & w tys. \\
\hline Wyższe & 1,5 & 2,6 & 69,38 \\
Policealne oraz średnie zawodowe & 20,2 & 20,8 & 561,90 \\
Średnie ogólnokształcące & 7,2 & 6,2 & 168,74 \\
Zasadnicze zawodowe & 39,0 & 37,0 & 998,76 \\
Podstawowe i bez wykształcenia & 32,1 & 33,4 & 903,80 \\
\hline razem & 100,0 & 100,0 & 2702,5 \\
\hline
\end{tabular}

Źródło : Mały rocznik statystyczny, GUS, Warszawa 2001, s. 151.

Jak zauważamy, proporcje bezrobotnych wg poziomu wykształcenia ulegają niewielkim zmianom. Wśród bezrobotnych rośnie liczba osób z wykształceniem średnim zawodowym, z wykształceniem podstawowym, bez wykształcenia i z wykształceniem wyższym. Taka tendencja wynika z rozwijanego w naszym kraju modelu oświaty zawodowej, dostosowanego do warunków, kiedy państwo wytyczało kierunki kształcenia i zapewniało miejsce 
pracy każdemu absolwentowi. Stąd powszechnie panuje opinia, że szkolnictwo zawodowe w Polsce kształci bezrobotnych.

Również w przypadku absolwentów szkół wyższych, skupiających się w dużych ośrodkach akademickich, potęgują się trudności ze znalezieniem pracy, szczególnie adekwatnej do wykształcenia $\mathrm{W}$ związku z powyższym wyłania się istotna kwestia przydatności kształcenia $\mathrm{w}$ wielu zawodach do zmieniającego się rynku pracy, tym bardziej, że podstawowym rodzajem bezrobocia w Polsce jest bezrobocie strukturalne.

Staż pracy łączy się ściśle z wiekiem pracownika. Zazwyczaj osoby o większym stażu należą do starszych grup wiekowych. Grupa o najdłuższym stażu (powyżej 30 lat) jest najmniej zagrożona bezrobociem (tylko $0,7 \%$ ogółu bezrobotnych) w przeciwieństwie do bezrobotnych bez jakiegokolwiek stażu $(23,7 \%)$ oraz osób o niskim stażu do 5 lat, które stanowią łącznie aż 35,7 \% bezrobotnych (tab. 5). $Z$ tego powodu młodzi ludzie często decydują się na podjęcie pracy na tzw. okres próbny lub odbycie stażu w danej firmie, byleby tylko gdzieś się ,załapać” i zdobyć doświadczenie oraz żeby powiększać jednocześnie swój okres czasu pracy, tak przecież liczony przez przyszłych pracodawców.

W strukturze bezrobotnych przeważają kobiety, stanowiące w 2000 roku 55,2\% ogółu bezrobotnych. Jednocześnie udział kobiet wśród bezrobotnych systematycznie wzrasta, co wynika z faktu, że stanowią ogółem liczebniejszą grupę (współczynnik feminizacji w Polsce wynosi obecnie 106 kobiet /100 mężczyzn) oraz z faktu, że są one bardziej zagrożone utratą pracy niż mężczyźni. Pracodawcy wolą zatrudnić mężczyznę wiedząc, że kobieta może korzystać z przysługującego jej prawa do urlopu macierzyńskiego czy wychowawczego lub po prostu częściej korzystać z absencji w pracy, tytułem opieki nad dzieckiem.

W strukturze bezrobocia należy uwzględnić również czas pozostawienia bez pracy (tab. 5). Najwięcej jest bezrobotnych powyżej jednego roku pozostawania bez pracy, którzy stanowili w 2000 roku łącznie 44,6\% ogółu poszukujących pracy, co wynika zasadniczo z dwóch przyczyn. $Z$ jednej strony bezrobotni z dużym ,stażem bezrobocia” mają obniżone poczucie własnej wartości oraz łatwo narażeni są na wpływy patologiczne. Szczególnie pogłębia się ten proces przy bezrobociu dziedzicznym. Zjawisko to znane jest na terenie Polski wśród dzieci bezrobotnych rodziców byłych PGR-ów (Grzywacz 2002). Wystepuje ono również nie tylko $\mathrm{w}$ krajach słabo rozwiniętych, ale i w USA. Z drugiej strony pracodawcy niechętnie przyjmują osoby z długim okresem „wyłączenia z pracy”, gdyż obawiają się różnych niekorzystnych następstw takiego stanu rzeczy.

W opinii publicznej wciąż jeszcze panuje pogląd o większej aktywności i zaradności ludzi pracujących w stosunku do bezrobotnych, co niestety podczas szukania pracy odbija się niekorzystnie na tych ostatnich.

Tab. 5 Bezrobocie w Polsce wg stażu pracy oraz czasu pozostawania bez pracy (w $2000 \mathrm{r}$.)

\begin{tabular}{|l|r|r|l|c|}
\hline \multirow{2}{*}{ Wyszczególnienie } & \multicolumn{2}{|c|}{ Wg stażu pracy } & Wyszczególnienie & $\begin{array}{c}\text { Wg czasu pozost. } \\
\text { bez pracy w \% }\end{array}$ \\
\cline { 2 - 3 } & w tys. & w \% & & 22,0 \\
Bez stażu pracy & 643,3 & 23,7 & 3 miesiące i mniej & 15,5 \\
Ze stażem pracy: & & & 3-6 miesięcy & 17,9 \\
1 rok i mniej & 470,3 & 17,4 & $6-12$ miesięcy & 22,1 \\
$1-5$ & 493,2 & 18,3 & $12-24$ miesięcy & 22,5 \\
$5-10$ & 345,3 & 12,8 & powyżej 24 miesięcy & \\
$10-20$ & 465,3 & 17,2 & & \\
$20-30$ & 267,1 & 9,9 & & 100,0 \\
powyżej 30 lat & 18,1 & 0,7 & & \\
\hline Razem & 2702,6 & 100,0 & Razem & \\
\hline
\end{tabular}

Źródło :Rocznik statystyczny, GUS, Warszawa 2001, s. 151, Krajowy Urząd Pracy 
Stopa bezrobocia wykazuje też dynamikę zmian w ciągu roku. W każdym roku miesiące IV, V i częściowo VI są okresami spadku liczby zarejestrowanych bezrobotnych. Taka sytuacja wynika $\mathrm{z}$ rozpoczęcia $\mathrm{w}$ tym czasie prac sezonowych $\mathrm{w}$ budownictwie i rolnictwie a także początkiem sezonu turystycznego. Z kolei pod koniec czerwca, a w szczególności od lipca, następuje nasilenie bezrobocia, gdyż po zakończeniu roku szkolnego wielu absolwentów rejestruje się po raz pierwszy w urzędach pracy, zyskując tym samym status bezrobotnego. Również wzrost bezrobotnych przypada na początek i koniec roku, gdyż do ewidencji trafiają wtedy osoby, którym z końcem roku wygasają umowy o pracę oraz w miesiącach zimowych nie podejmowane są prace interwencyjne ze strony władz administracyjnych.

Problemem polskiego rynku pracy jest również obok wzrastającej stopy bezrobocia jej rosnące zróżnicowanie przestrzenne. Najwyższa stopa bezrobocia występuje w obszarach Polski północnej, północno-wschodniej i północno-zachodniej (tab. 6). Wyróżniają się tutaj takie województwa jak: warmińsko- mazurskie $(24,5 \%)$, lubuskie $(20,5 \%)$ oraz zachodniopomorskie $(20,5 \%)$. Są to słabo rozwinięte gospodarczo rolnicze regiony, dodatkowo obciążone konsekwencjami likwidacji państwowych gospodarstw rolnych. Za przyczynę tego stanu rzeczy podaje się niskie kwalifikacje zawodowe tamtejszej ludności wiejskiej, małą mobilność zawodową i przestrzenną, co powoduje, że ograniczenie bezrobocia na tych obszarach jest zadaniem niezwykle trudnym. (Padowicz 2002).

Tablica 6. Bezrobotni zarejestrowani wg województw w Polsce (2000)

\begin{tabular}{|c|c|c|c|c|c|c|}
\hline \multirow[t]{2}{*}{ Województwa } & \multirow{2}{*}{$\begin{array}{l}\text { Ludność } \\
\text { w tys. }\end{array}$} & \multicolumn{2}{|c|}{ Pracujący } & \multicolumn{2}{|c|}{ Bezrobotni zarejestr. } & \multirow{2}{*}{$\begin{array}{l}\text { Stopa bez- } \\
\text { robocia rej. }\end{array}$} \\
\hline & & w tys. & w \% & w tys. & w \% & \\
\hline Dolnośląskie & 2975,1 & 1034,6 & 6,7 & 231,7 & 8,6 & 18,1 \\
\hline Kujawsko- pomorkie & 2101,1 & 753,7 & 4,9 & 181,2 & 6,7 & 19,4 \\
\hline Lubelskie & 2233,3 & 979,5 & 6,4 & 159,7 & 5,9 & 14,0 \\
\hline Lubuskie & 1023,8 & 344,6 & 2,2 & 89,1 & 3,3 & 20,5 \\
\hline Łódzkie & 2647,8 & 1085,8 & 7,1 & 208,1 & 7,7 & 16,1 \\
\hline Małopolskie & 3226,6 & 1365,9 & 8,9 & 185,2 & 6,9 & 11,9 \\
\hline Mazowieckie & 5068,7 & 2407,6 & 15,7 & 289,9 & 10,7 & 11,1 \\
\hline Oplskie & 1086,6 & 374,5 & 2,4 & 69,3 & 2,6 & 15,3 \\
\hline Podkarpackie & 2127,9 & 952,2 & 6,2 & 182,2 & 6,7 & 15,9 \\
\hline Podlaskie & 1222,0 & 495,4 & 3,2 & 79,2 & 2,9 & 13,7 \\
\hline Pomorskie & 2194,6 & 763,4 & 5,0 & 147,2 & 5,4 & 16,2 \\
\hline Śląskie & 4857,9 & 1774,8 & 11,6 & 259,8 & 9,6 & 12,8 \\
\hline Świętokrzyskie & 1323,7 & 593,1 & 3,9 & 118,5 & 4,4 & 16,5 \\
\hline Warmińsko-mazurskie & 1466,2 & 473,1 & 3,1 & 158,2 & 5,9 & 24,5 \\
\hline Wielkopolskie & 3357,5 & 1374,1 & 9,0 & 193,3 & 7,2 & 12,3 \\
\hline Zachodniopomorskie & 1733,4 & 572,8 & 3,7 & 150,1 & 5,6 & 20,5 \\
\hline Polska & 38646,2 & 15345,1 & 100,0 & 2702,6 & 100,0 & 15,0 \\
\hline
\end{tabular}

Źródło: Rocznik statystyczny GUS, Warszawa 2001

Najniższa stopa bezrobocia występuje natomiast w Polsce południowej i środkowej, a szczególnie w województwach: mazowieckim $(11,1 \%)$, małopolskim $(11,9 \%)$, wielkopolskim $(12,3 \%)$ i śląskim $(12,8 \%)$, gdyż są to najbardziej uprzemysłowione i zurbanizowane regiony kraju o dużym zatrudnieniu w sektorze przemysłu i usług.

Nowy podział administracyjny kraju, wprowadzony od 1999 roku, „spłaszczył” nieco zróżnicowanie stopy bezrobocia. I tak rozpiętość przedziału wielkości wskaźnika stopy bezrobocia tj. różnica między maksymalną a minimalną stopą bezrobocia wynosiła dla przykładu 14,4\% w roku 1991, 18,2\% w roku 1992, aż 23,6\% w roku 1996, by w roku 2000 osiągnąć wartość „tylko”13,4\%.

W 2000 roku stopę bezrobocia poniżej wartości krajowej zanotowano w sześciu województwach :mazowieckim, małopolskim, wielkopolskim, śląskim, podlaskim oraz lubel- 
skim. W 10 pozostałych województwach stopa bezrobocia przekroczyła wartość średniej krajowej, czyli 15\%.

Analizując poziom bezrobocia, wyrażany w wartościach bezwzględnych, zauważamy również jego zróżnicowanie regionalne, co wynika z różnic w proporcji liczby ludności aktywnej zawodowo, zamieszkującej na terenie danego województwa. I tak w końcu 2000 roku najwięcej zarejestrowanych bezrobotnych było w województwach o najwyższym potencjale ludności aktywnej zawodowo, tj. mazowieckim (289,9 tys.), śląskim (259,8 tys.), dolnośląskim (231,7 tys.) oraz małopolskim (208,1 tys.).

Z kolei najmniejszą liczbę bezrobotnych odnotowano w województwach: opolskim (69,3 tys.), podlaskim (79,2 tys.) oraz lubuskim (89,1 tys.).

W literaturze przedmiotu stwierdza się, że nie ma wyraźnej zależności między rozmiarami bezrobocia a stopą bezrobocia (Zioło 1993). Potwierdza się to także i obecnie (tab. 7).

Tab. 7. Relacje między liczbą bezrobotnych a stopą bezrobocia w grudniu $2001 \mathrm{r}$.

\begin{tabular}{|l|c|c|c|c|c|c|c|}
\hline Liczba bezrobot- & Liczba & \multicolumn{7}{|c|}{ Stopa bezrobocia } \\
\cline { 3 - 8 } nych w tys. & woj. & $10-12$ & $12-14$ & $14-16$ & $16-18$ & $18-20$ & Pow. 20 \\
\hline Poniżej 100 tys. & 3 & & & 2 & & & \\
\hline $100-150$ tys. & 3 & & 1 & & 2 & & \\
\hline $150-200$ tys. & 7 & 1 & 2 & 1 & & 1 & 2 \\
\hline $200-250$ tys. & 2 & & & & 1 & 1 & \\
\hline $250-300$ tys. & 1 & 1 & & & & & \\
\hline Razem & 16 & 2 & 3 & 3 & 3 & 2 & 3 \\
\hline
\end{tabular}

Źródło: Obliczenia własne na podstawie rocznika statystyczny, GUS, Warszawa 2001

Największa liczba województw (7) charakteryzuje się przewagą bezrobotnych w przedziale od 150-200 tys. Natomiast najwyższa stopa bezrobocia (powyżej 20\%) występuje w dwóch przedziałach liczby bezrobotnych, wahających się od 150-200 tys. oraz poniżej 100 tysięcy.

O ile wg statystyk wyższe stopy bezrobocia dotyczą miasta niż wsi o tyle bezrobocie wiejskie jest o wiele trwalsze a panujący tam rynek pracy o wiele mniej podatny na zmiany. Szczególnie w trudnej sytuacji znaleźli się byli pracownicy PGR-ów, głównie w tych wsiach, gdzie pegeer był jedynym zakładem pracy. Ponadto wartość bezrobocia ukrytego na wsiach, jest wysoce zaniżona (szacuje się ją w przedziale 0,8-1,2 mln), co oznaczać może w przyszłości prawie dwukrotny wzrost jawnego bezrobocia w obszarach pozamiejskich.

Wyższe stopy bezrobocia $\mathrm{w}$ miastach wynikają $\mathrm{z}$ procesów restrukturyzacji oraz $\mathrm{z}$ trudności sprostania konkurencji na rynku dóbr przemysłowych. W 2000 roku w liczbie bezrobotnych znajdowało się 1180,2 tysięcy osób zamieszkałych na wsi, co stanowiło 43,7\% ogólnej liczby bezrobotnych.

Również wzrost bezrobocia jest wyższy w miastach niż na wsi. W latach 1999-2000 liczba bezrobotnych na wsi wzrosła o 124,7 tys. a w mieście odpowiednio o 228 tys., co jest wynikiem postępującej prywatyzacji i restrukturyzacji przedsiębiorstw, dotykających obszarów o większej liczebności siły roboczej (Padowicz 2002).

$\mathrm{Na}$ wsi obok bezrobocia ukrytego poważnym problemem staje się przeludnienie agrarne nieporównywalne do krajów UE. O ile bowiem współczynnik zatrudnienia w rolnictwie polskim wynosi około $27 \%$, o tyle w Europie Zachodniej zaledwie 6\%. Bezrobocie pogłębia niski poziom wykształcenia rolników, zmniejszający ich szanse zatrudnienia.

Najtrudniejsza sytuacja na rynku pracy w woj. rolniczych występuje wzdłuż pdwsch. granicy kraju oraz na północy. Rozpiętość stopy bezrobotnych zamieszkałych na wsi jest ponad 3-krotnie wyższa od analogicznej średniej krajowej i wynosi aż 45,8 \% z warto- 
ściami skrajnymi w woj. podlaskim $(64,6 \%$ bezrobotnych na wsi w stosunku do ogółu ludności) i śląskim (analogicznie 18,8\%).

Według GUS w październiku 2002 roku liczba bezrobotnych zmniejszyła się o 4,5 tys. w stosunku do września br., a tym samym stopa bezrobocia spadła z 17,6 do $17,5 \%$. Spadek ten, choć niewielki jest o tyle istotny, że we wrześniu i październiku bezrobotnych zazwyczaj przybywa. Było to wynikiem większej ilości ofert pracy - 54 tys. (październik 2002) wobec 52,7 tys. (wrzesień 2002).

Zdaniem ekonomistów sytuacja na rynku pracy jest gorsza niż to wynika ze statystyki bezrobocia rejestrowanego. Niestety już 83 \% bezrobotnych nie ma prawa do zasiłku. Możemy się też spodziewać dalszych zwolnień - w październiku pracownicy zadeklarowali chęć zwolnienia 60,7 tys. osób, czyli o prawie 2 tys. więcej niż przed miesiącem. Ponadto wg BAEL w III kwartale 2002 r. stopa bezrobocia spadła tylko o 0,1 pkt proc. do 19,8 \%, zważywszy na to, że lato to najlepszy czas na znalezienie pracy, a wzrost gospodarczy wyniósł już 2 proc. PKB.

Trudno na tej podstawie określić czy osiągniemy planowaną na koniec 2002 roku wartość stopy bezrobocia równą $18,2 \%$. Biorąc pod uwagę przewidywany wzrost bezrobocia można obawiać się pogłębienia trudności na rynku pracy, w odniesieniu szczególnie do młodzieży, osób o niskich kwalifikacjach, długotrwale bezrobotnych oraz na obszarach słabo rozwiniętych.

Przesłanki poprawy na rynku pracy oraz w zatrudnieniu nadal nie są pomyślne. $\mathrm{W}$ tej sytuacji konieczne jest rozszerzenie prozatrudnieniowej polityki państwa oraz zwiększenie interwencyjnych działań instytucji na lokalnym rynku pracy.

Rządowy program gospodarczy „Przedsiębiorczość, rozwój, praca” umiejscowił problem bezrobocia w następujących wymiarach czasowych. Rok 2002 to „gaszenie pożaru” czyli zatrzymanie wzrostu bezrobocia. Podjęto w tym celu program „Pierwsza praca”, który obejmuje np. obniżenie płacy minimalnej dla absolwentów czy inicjatywę ,podzielenia się pracą" ( $\mathrm{tj}$. wprowadzenia ograniczeń $\mathrm{w}$ łączeniu emerytury i rent $\mathrm{z}$ dochodami $\mathrm{z}$ pracy). Ponadto rząd poprzez zmianę kodeksu pracy dąży do wzrostu ożywienia gospodarczego $\mathrm{w}$ kraju. Po roku 2004 przewiduje się znaczny wzrost gospodarczy oraz pojawią się fundusze unijne, co wpłynie na zapewnienie miejsc pracy i obniżenie stopy bezrobocia. Jeśli rząd nie podejmie stosownych działań, to stopa bezrobocia może osiągnąć w najbardziej pesymistycznej wersji wartość aż $20 \%$.

\section{SPECYFIKA BEZROBOCIA W POLSCE - WNIOSKI KOŃCOWE} wnioski :

W świetle analizy przyczyn i struktury bezrobocia w Polsce nasuwają się następujące

- Szybkie powstanie i narastanie bezrobocia w Polsce po roku 1989.

- Duże zróżnicowanie terytorialne stopy bezrobocia.

- Dalszy, wysoki stopień bezrobocia ukrytego, szczególnie na wsiach.

- Wyższe bezrobocie w miastach niż na wsiach.

- Wyższe bezrobocie wśród kobiet.

- Wysoki udział bezrobotnych z wykształceniem zasadniczym zawodowym oraz z podstawowym pełnym i niepełnym.

- Przewaga wśród bezrobotnych osób młodych, do 35 lat oraz z małym stażem pracy lub bez stażu.

- Utrzymujący się wysoki odsetek bezrobotnych z długim (powyżej roku) czasem pozostawania bez pracy.

- Powyżej 2-krotnie większe bezrobocie w Polsce na tle UE. 
- Niska mobilność, wynikająca z zaniedbań rozwoju infrastruktury, regionalnymi różnicami w kosztach wynajmu i zakupu mieszkania oraz niskim poziomem motywacji do pracy, będącej następstwem m.in. niskiego wynagrodzenia (Oleksyn 1991).

- Niska przedsiębiorczość i zaradność jako cechy specyficzne naszego społeczeństwa nabyte poprzez nadopiekuńczość państwa w byłym systemie.

- Niski poziom tzw „infrastruktury przedsiębiorczości” czyli instytucji wspomagających znalezienie pracy.

\section{LITERATURA}

Dach Z., Rynek pracy. [w:] Transformacja systemu ekonomicznego w Polsce. Praca zbiorowa pod red. Stanisława Lisa, PAN, Prace Komisji Nauk Ekonomicznych 1994, nr 18, s. $65-80$

Dach Z., Bezrobocie w okresie przemian systemowych gospodarki polskiej, Prace Komisji Nauk Ekonomicznych, Zakład Narodowy im. Ossolińskich, Wrocław 1993-98, s. 20-93

Elementarne zagadnienia ekonomii. Praca zbiorowa pod red. R. Milewskiego, PWN, Warszawa 1994

Frąckiewicz L., Bezrobocie jako problem społeczny. Polityka społeczna 1991, nr 10, s. 4-5

Grzywacz W., Podstawy makroekonomii, PWN, Warszawa 2002

Koptas G., Społeczno-psychologiczne nastepstwa bezrobocia, Polityka społeczna 1992, nr 1, s. $16-18$

Nasiłowski M. System rynkowy, Key Text, Warszawa 2002, s. 294-320

Oleksyn T. Bezrobocie w Polsce -przyczyny, specyfika, przeciwdziałanie . Praca i zabezpieczenie społeczne 1991, nr 4, s. 11-17

Padowicz W., Rosnace bezrobocie i kryzys zatrudnienia w Polsce (przyczyny i uwarunkowania), Praca i zabezpieczenie społeczne 2002, nr 1, s. 2-11

Polityka ekonomiczna, pod red. A. Fajferka, Wydawnictwo AE w Krakowie, Kraków 1999, s. $221-230$

Polityka gospodarcza, pod red. B. Winiarskiego PWN, Warszawa 1999, s. 467-489

Zioło Z., Przemiany krajowych i regionalnych struktur bezrobocia w Polsce. [w:] Krajowy, regionalne i lokalne rynki pracy w Polsce na początku lat dziewięćdziesiątych, Biuletyn PAN 1993, nr 161, s. 41-61

Zioło I., Zioło Z., Rozmiary bezrobocia w Polsce [w:] 41. Zjazd Polskiego Towarzystwa Geograficznego i Konferencja Geografia i aktualne problemy miasta Krakowa i regionu. Oddział Krakowski PTG, Instytut Geografii UJ i AP, Kraków 1992, s. 172-174

Strony internetowe:

- www.praca.targi.com

- www.praca.onet.pl

- www.twojakariera.pl

- www.jobs.pl 